\title{
Identification of Leishmania spp. in horses and a dog from rural areas of Uruguaiana, Rio Grande do Sul, Brazil
}

\section{Identificação de Leishmania spp. em equinos e um cão da área rural de Uruguaiana, Rio Grande do Sul, Brasil}

\author{
Gabriela Döwich Pradella ${ }^{1 *}$; Taiane Acunha Escobar²; Claudia Acosta Duarte ${ }^{3}$; \\ Irina Lübeck ${ }^{4}$; Geórgia Camargo Góss ${ }^{5}$; Luís Felipe Jaenisch Lagreca ${ }^{6}$; \\ Gabriel Feix Heckler7; Lilian Pinto Camargo ${ }^{8}$; Bruno Gostinski Romero ${ }^{9}$
}

\section{Highlights:}

Equine Leishmania infantum infection was confirmed by polymerase chain reaction analysis of peripheral blood samples and sequencing of one positive sample.

This is the first report to describe equine and canine infection by Leishmania spp. in animals from rural areas of Rio Grande do Sul western border.

All horses and dogs with Leishmania spp. infection were asymptomatic for visceral leishmaniasis at the time of sample collection and clinical evaluation.

\begin{abstract}
Visceral leishmaniasis (VL) is a zoonosis caused by the protozoan of the genus Leishmania. The disease is transmitted by the bite of a sand fly vector. Although the main reservoirs are dogs, other hosts can be infected and may play this role. Rio Grande do Sul western region, located on the triple border of Brazil-Uruguay-Argentina, represents a VL transmission area. The goal of the present study was to identify Leishmania spp. infection in animals from rural areas of Uruguaiana, Rio Grande do Sul. Nine farms in the Uruguaiana municipality, Rio Grande do Sul state, were included. Peripheral blood samples were collected from 113 animals (canine [n=22], equine [n=91]) for detection of Leishmania spp. DNA was isolated and polymerase chain reaction was performed. Eight (7\%) animals with Leishmania spp. infection were detected on two farms in the same geographical area, seven of which were horses and one was canine, all of which were asymptomatic. To investigate the species of Leishmania, one of the positive equine samples was subjected to direct sequencing, which confirmed the presence of $L$.
\end{abstract}

1 Discente do Curso de Mestrado, Programa de pós-graduação em ciência animal, Universidade Federal do Pampa, UNIPAMPA, Uruguaiana, RS, Brasil. E-mail: gabrieladowich@hotmail.com

2 Prof ${ }^{\mathrm{a}}$ Dr $^{\mathrm{a}}$, Pesquisadora, Curso de Graduação em Fisioterapia e Enfermagem, UNIPAMPA, Uruguaiana, RS, Brasil. E-mail: taianeescobar@hotmail.com

3 Prof ${ }^{a}$ Dr $^{a}$, Pesquisadora do Curso de Graduação em Medicina Veterinária e do Curso de Mestrado do Programa de Pós-Graduação em Ciência Animal, UNIPAMPA, Uruguaiana, RS, Brasil. E-mail: claudiaduarte@unipampa.edu.br

4 Prof ${ }^{\mathrm{a}} \mathrm{Dr}^{\mathrm{a}}$, Pesquisadora do Curso de Graduação em Medicina Veterinária, UNIPAMPA, Uruguaiana, RS, Brasil. E-mail: ilubeck@ gmail.com

5 Discente do Curso de Mestrado, Programa de Pós-Graduação em Ciência Animal, UNIPAMPA, Uruguaiana, RS, Brasil. E-mail: georgia goss@hotmail.com

6 Médico Veterinário Autônomo, UNIPAMPA, Uruguaiana, RS, Brasil. E-mail: luisfelipelagreca@gmail.com

7 Discente do Curso de Graduação em Medicina Veterinária, UNIPAMPA, Uruguaiana, RS, Brasil. E-mail: hecklergabriel@ gmail.com

8 Médica Veterinária Autônoma, UNIPAMPA, Uruguaiana, RS, Brasil. E-mail: liliancamargo@hotmail.com

9 Discente do Curso de Graduação em Medicina Veterinária, UNIPAMPA, Uruguaiana, RS, Brasil. E-mail: b.g.romero2014@ gmail.com

* Author for correspondence 
infantum genetic material. Results of this study confirm the presence of $L$. infantum-infected animals in rural areas of Uruguaiana, and provide evidence supporting further investigation of risk factors for dissemination in such areas.

Key words: Domestic animals. Leishmaniasis. PCR. Public health. Western border.

\title{
Resumo
}

\begin{abstract}
A leishmaniose visceral é uma zoonose causada por protozoários do gênero Leishmania. A doença é transmitida pela picada de um vetor flebotomíneo. Os principais reservatórios são cães, porém outros mamíferos podem se infectar e desempenhar esse papel. A região oeste do Rio Grande do Sul, localizada na tríplice fronteira Brasil-Uruguai-Argentina, representa uma área de transmissão para a leishmaniose visceral. O objetivo deste estudo foi identificar a infecção por Leishmania spp. em animais de áreas rurais de Uruguaiana, Rio Grande do Sul. Nove fazendas do município de Uruguaiana, no Rio Grande do Sul, and foram incluídas. O sangue periférico foi coletado de 113 animais, caninos $(n=22)$ e equinos ( $\mathrm{n}=91$ ), para a pesquisa de DNA de Leishmania spp. por reação em cadeia da polimerase (PCR). Oito animais infectados por Leishmania spp. (7\%) foram detectados em duas fazendas na mesma área geográfica, sete equinos e um canino. Todos eles eram assintomáticos. Para investigar as espécies de Leishmania, uma das amostras positivas da espécie equina, também foi submetida ao sequenciamento e a presença de material genético de $L$. infantum foi confirmada. Este estudo garante a existência de animais infectados por Leishmania infantum nas áreas rurais de Uruguaiana e evidencia a importância de estudos para investigar os fatores de risco de disseminação nestes locais.
\end{abstract}

Palavras-chave: Animais domésticos. Leishmaniose. PCR. Saúde pública. Fronteira oeste.

\section{Introduction}

In Brazil, human visceral leishmaniasis (VL) is present in 26 of the 27 federative units; Acre is the only state that does not have a case notification system. The cases registered in Rondonia, Amazonas, and Amapa states were not autochthones, they were individual residents in these states, with the infection acquired in another state (Sistema de Informação de Agravos de Notificação [SINAN], Secretaria de Vigilância em Saúde [SVS], Ministério da Saúde [MS], 2019). VL is caused by the etiological agent Leishmania infantum, which is transmitted by phlebotomine sand flies (Centers for Disease Control and Prevention, 2017) infecting different animal species (Benassi et al., 2018; Costa et al., 2010). In the past, VL was characterized as a zoonosis in rural areas; however, it has spread into urban areas and has become a serious public health problem in several states of the country (Organización Panamericana de la Salud [OPS], 2019).

Human VL (HVL) cases emerged at state borders in 2009. Later, the disease was reported in central areas of the states, totaling 31 cases (Centro Estadual de Vigilância em Saúde [CEVS], 2019). All reports involved animals and humans residing in urban areas. Rio Grande do Sul western region, located on the triple border of Brazil-Uruguay-Argentina, represents a VL transmission area. Since 2011, it has been classified as an area of extreme epidemiological importance (Deboni, Barbosa, \& Ramos, 2011), with reports of the vector and infection in humans and canines in the Corrientes province of Argentina (Berrozpe et al., 2017), and in departments of Artigas and Salto in Uruguay (Salomón, Basmajdian, Fernández, \& Santini, 2011).

To date, there have been no reports of infection or an epidemiological chain in rural areas of Rio Grande do Sul western border municipalities. However, there is a spread of canine VL (CVL) and transmission of HVL in urban areas of these municipalities, indicating the need to investigate VL progression to other environments (CEVS, 2017). Infection of horses has already been found in urban areas of Uruguaiana municipality using polymerase 
chain reaction (PCR) techniques (Escobar et al., 2019a) and that fact demonstrate the importance of research in this area. Herein, we have identified the infecting Leishmania species in dogs and horses from the south of Brazil, a new outbreak of the infection. The present study aimed to detect Leishmania spp. infection in equines and canines from rural areas of Uruguaiana, Rio Grande do Sul on the triple border, and to confirm the parasite species involved using sequencing analysis of any positive samples.

\section{Material and Methods}

\section{Ethics approval and consent to participate}

The study was approved by the Ethics Committee on Animal Use (CEUA) of the Federal University of Pampa (UNIPAMPA), protocol number 031/2017. The tutors of the animals authorized the use of biological materials and information for clinical assessments.

\section{Study location}

Uruguaiana is a city $5,702,098 \mathrm{~km}^{2}$ in size, bathed by the Uruguay River. The countryside is approximately 5,301,49 $\mathrm{km}^{2}$ and is distributed across 1116 farms. The main industries are cattle breeding, equine, and rice culture. The population of the city is 125,435 , with 117,415 residing in urban zones and 8020 in rural areas (Instituto Brasileiro de Geografia e Estatística [IBGE], 2017).

\section{Study population}

The present study was conducted on nine farms from the southwest, northeast, and east rural areas of Uruguaiana municipality on the Rio Grande do Sul western border (identified by numbers 1 to 9 in Figure 1). This area borders the neighboring countries of Argentina to the west and Uruguay to the south.

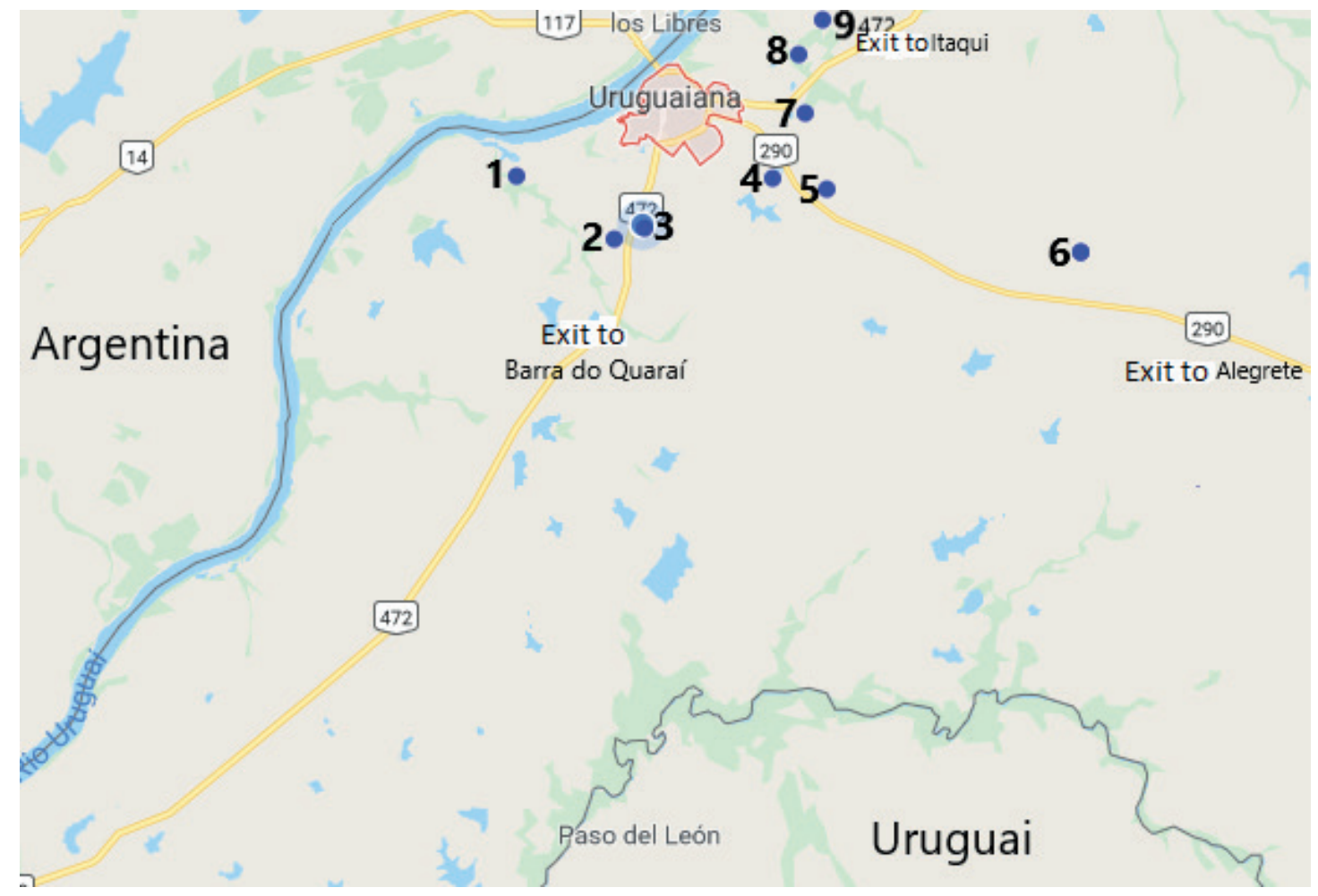

Figure 1. Map illustrating the distribution of rural properties (numbered 1 to 9) in the western frontier of Rio Grande do Sul, Brazil, where the biological material was collected. Positive animals were from rural properties 1 and 2 . 
The samples were selected according to availability; at the time of collection, a total of 113 animals (91 horses, 22 dogs) were tested, with owners' consent to comply with the Brazilian national guidelines on animal experimentation. Samples were collected from animals on three farms in each geographical coordinate between July and December 2017, as follows: southwest (30 horses, five dogs); east ( 31 horses, eight dogs); and northeast (30 horses, nine dogs). The animals were identified by numbers and underwent clinical evaluation (heart rate, respiratory rate, mucous membranes, rectal temperature and lymph node[s] palpation and abdominal palpation in dogs). Alopecia, skin lesions, and weight loss were also noted.

\section{Biological samples}

Peripheral blood was collected by venipuncture of the external jugular vein in horses and external jugular or cephalic veins in dogs. Blood was collected in tubes with anticoagulant EDTA (i.e., ethylene diamine tetraacetic acid) for molecular analysis.

\section{Molecular analysis}

DNA was extracted using the salting-out technique (Sambrook \& Russel, 2001) and a standardized volume of blood $(300 \mu \mathrm{L})$, followed by conventional PCR. The primers used to identify Leishmania spp. infection were RV1/ RV2, which amplify the kinetoplast DNA minicircle; here, the fragment was 145 base pairs in length and specific for the Donovani complex (Lachaud et al., 2002). To confirm the Donovani complex PCR pair, one of the positive equine samples was purified using a commercially available kit (Purelink Kit ${ }^{\mathrm{TM}}$ Quick Gel Extraction and PCR Purification kit, Invitrogen, USA), according to manufacturer's instructions. Direct sequencing of amplified PCR fragments (both strands) was performed using an automated sequencer (ABI-Prism 3500 Genetic analyzer, Applied Biosystems, USA).

\section{Results and Discussion}

Dogs are the domestic reservoir for L. infantum in endemic areas, and contribute significantly to the maintenance of infection, mainly in urban areas (Dantas-Torres, 2007). In Uruguaiana, canine disease is widespread in virtually all neighborhoods, which fortifies the endemicity of CVL in this region (Escobar et al., 2018). Another important fact is the presence of Leishmania spp. infection in horses from urban areas of Uruguaiana (Escobar et al., 2019a,b) which demonstrates that the species is in contact with the disease and that there is an attraction of sandflies for the same. Although the role of mammals, such as horses, in the leishmaniasis cycle is not entirely clear, the fact that they are a source of food for the vectors contributes to the maintenance of Leishmania spp. infection in the environment (Feitosa et al., 2012).

Among the 113 animals sampled, L. infantum DNA was detected in the peripheral blood of 7 (6.19\%) horses and $1(0.88 \%)$ dog. All animals were asymptomatic for VL at the time of collection and clinical evaluation. PCR enables the identification of low levels of parasitic infection in biological samples. This method enables the amplification of DNA sequences specific to the parasite (Iniesta et. al., 2002). The amplified kDNA minicircle regions, such as the LT1 region with a 145 base pair fragment using RV1/RV2 primers, are very useful because of their high sensitivity. However, polymorphisms among minicircles can be a limitation to differentiating species (Ceccarelli et al., 2017).

The resulting PCR product of one positive sample was treated to remove excess primers and nucleotides and subsequently sequenced. This technique was performed after PCR because it enabled the selection of regions of a genome of interest (Sambrook \& Russel, 2001). Sequencing analysis enabled the identification of major similarity of the positive sample with the species L. infantum (GenBank accession 103741.1; query cover $96 \%$; ident $93 \%$ ). A previous study reported 
infection in 14/28 (50\%) dog and 11/95 (11.6\%) horse blood samples collected from urban areas of Uruguaiana (Escobar et al., 2019a). In a later study, the same group found $96 \%$ homology to L. infantum (GenBank Accession No. L 19877.1) (Escobar, 2019b) corroborating with our findings.

All infected animals (horses and dogs) belonged to two farms in the southwest. The region has access by BR 472 in the direction to Barra do Quaraí municipality, bordering with Uruguay, with transit of vehicles and animals from one country to another, thus permitting greater exposure. According to the map (Figure 1), the proximity to Argentina and Uruguay river is apparent. There is a hypothesis regarding significant adaptation of the vector along the border of large rivers, such as the Uruguay River, and the dissemination of the infection in these areas (Satragno et al., 2017). Aside from three horses, a dog on farm 2 was also diagnosed. On the other farm, there was no Leishmania infection in dogs, but four horses were positive. Access is by asphalted main roads (BR 290 and BR 472) before vicinal roads without asphalt, located near the main roads of Itaqui, Alegrete, and Barra do Quaraí municipalities (Figure 1).

Findings of the present study are extremely important for public health in Latin America, with a view to the identification of $L$. infantum, a causative agent of CVL and HVL (Mahmud, Piassini, Motta, Behar, \& Souza, 2019) in a Brazilian zone bordering two countries that, until 2008, were free from infection (Salomón et al., 2008).

CVL is considered to be endemic in urban areas of Uruguaiana, being identified in dogs in all neighborhoods (Escobar et al., 2018). However, L. infantum infection in rural areas has not been reported until now. These data provide supportive evidence that the vector is well adapted to the climatic conditions and is achieving its physiological and nutritional needs from the blood of animals in this region. We are unsure whether wild animals are involved in the epidemiological chain; however, we can report that dogs and horses domiciled in the rural regions of the western border are acting as hosts to the etiological agent of VL.

In the northeast of Brazil, an epidemiological survey was performed in dogs from urban and rural areas, where a higher percentage of infected animals was found in the rural area (Amóra et al., 2006). In the southern region-Parana state-phlebotomine fauna in urban and rural areas were captured and identified (Rosa Cruz, Rosa Cruz, \& Galati, 2013).

These infected horses were exposed to $L$. infantum due to contact with wild animals or even abandoned dogs on the highway. The farm with positive animals ( $1 \mathrm{dog}$ and 3 horses) is located $<1 \mathrm{~km}$ from the highway (BR 472). It is known that dogs presenting clinical signs are commonly abandoned in the region. The other farm, with 4 positive horses and no infected dogs, is located near the Uruguay River, which supports the presence of positive animals in this area.

It is necessary to perform additional studies to identify and characterize possible reservoirs present in rural areas and possible risk factors for the dissemination of the infection. Moreover, our results support the need for studies using isolation and culture methods to characterize the species and their possible origins, given that infections clearly occur in border areas.

\section{Conclusion}

L. infantum infection was identified in peripheral blood samples obtained from domiciled animals in the rural area of Rio Grande do Sul state. These data provide evidence supporting the presence of the etiological agent of VL and the risk for infection rural areas.

\section{Acknowledgement}

The authors thank the research program for SUS, Shared Health Management - PPSUS: 2017, which financed the project. 


\section{References}

Amóra, S. S. A., Santos, M. J. P., Alves, N. D., Costa, S. C. G. da, Calabrese, K. da S., Monteiro, A. J., \& Rocha, M. F. G. (2006). Fatores relacionados com a positividade de cães para leishmaniose visceral em área endêmica do Estado do Rio Grande do Norte, Brasil. Ciência Rural, 36(6), 1854-1859. doi: 10. 1590/S0103-84782006000600029

Benassi, J. C., Benvenga, G. U., Ferreira, H. L., Soares, R. M., Silva, D. T., Pereira, V. F., Ruiz, V. L., Oliveira, T. M. F. de S. (2018). Molecular and serological detection of Leishmania spp. in horses from an endemic area for canine visceral leishmaniasis in southeastern Brazil. Pesquisa Veterinaria Brasileira, 38(6), 1058-1063. doi: 10.1590/1678-5150-PVB5214

Berrozpe, P., Lamattina, D., Santini, M. S., Araujo, A. V., Utgés, M. E., \& Salomón, O. D. (2017). Environmental suitability for Lutzomyia longipalpis in a subtropical city with a recently established visceral leishmaniasis transmission cycle, Argentina. Memorias Do Instituto Oswaldo Cruz, 112(10), 674680. doi: 10.1590/0074-02760170056

Ceccarelli, M., Galluzzi, L., Diotallevi, A., Andreoni, F., Fowler, H., Petersen, C., Vitale, F., Magnani, M. (2017). The use of kDNA minicircle subclass relative abundance to differentiate between Leishmania (L.) infantum and Leishmania ( L.) amazonensis. Parasites \& Vectors, 239(10), 1-10. doi: 10.1186/s1 3071-017-2181-x

Centers for Disease Control and Prevention (2017). Parasites- Leishmaniasis. CDC 24/7 Saving lives, Protecting people ${ }^{\mathrm{TM}}$. Recovered from https://www. cdc.gov/parasites/leishmaniasis/index.html

Centro Estadual de Vigilância em Saúde (2017). Situação epidemiológica da Leishmaniose Visceral no Rio Grande do Sul. Governo do Estado do Rio Grande do Sul / Secretaria de Saúde.

Centro Estadual de Vigilância em Saúde (2019). Leishmaniose visceral humana. Situação epidemiológica/dados. Recuperado de https://cevs. rs.gov.br/lvh-situacao-epidemiologica-dados

Costa, T. A. C., Rossi, C. N., Laurenti, M. D., Gomes, A. A. D., Vides, J. P., Sobrinho, L. S. V., \& Marcondes, M. (2010). Ocorrência de leishmaniose em gatos de área endêmica para leishmaniose visceral. Brazilian Journal of Veterinary Research and Animal Science, 47(3), 213-217. doi: 10.11606/ issn.1678-4456. bjvras. 2010.26858
Dantas-Torres, F. (2007). The role of dogs as reservoirs of Leishmania parasites, with emphasis on Leishmania (Leishmania) infantum and Leishmania (Viannia) braziliensis. Veterinary Parasitology, 149(3-4), 139146. doi: 10.1016/j.vetpar.2007.07.007

Deboni, S. C., Barbosa, M., \& Ramos, R. R. (2011). Vigilância epidemiológica de casos humanos. Boletim Epidemiológico. Porto Alegre: Centro Estadual de Vigilância Em Saúde [CEVS].

Escobar, T. A., Döwich, G., Cantele, L. C., Zuravski, L., Ferrareze, P. A. G., Duarte, C. A., Rosa e Silva, L. K., Lübeck, I., Manfredini, V. (2019a). Molecular detection of Leishmania spp. in Brazilian cross border south region mammalian hosts. Transboundary and Emerging Diseases, 476-480. doi: 10.1111/ tbed.13361

Escobar, T. A., Döwich, G., Santos, T. P. dos, Zuravski, L., Duarte, C. A., Lübeck, I., \& Manfredini, V. (2019b). Assessment of Leishmania infantum infection in equine populations in a canine visceral leishmaniosis transmission area. BMC Veterinary Research, 15(381), 1-9. doi: 10.1186/s12917-0192108-1

Escobar, T. A., Döwich, G., Zuravski, L., Cantele, L. C., Duarte, C. A., \& Lübeck, I. (2018). Risk factors associated to canine visceral leishmaniasis in uruguaiana city, Brazil. Semina: Ciencias Agrárias, 39(1), 211-220. doi: 10.5433/1679-0359.2018v39n1p211

Feitosa, F. L. F., Leal, J., Mendes, L. C. N., Peiró, J. R., Perri, S. H. V, Lima, V. M. F. de, \& Marcondes, M. (2012). Estudo soroepidemiológico de leishmaniose em equinos na região de Araçatuba-SP, Brasil, área endêmica para leishmaniose visceral. Brazilian Journal of Veterinary Research and Animal Science, $49(6)$, 500-502. doi: 10.11606/issn.1678-4456. v49i6p500-502.

Iniesta, L., Fernández-Barredo, S., Bulle, B., Gómez, M. T., Piarroux, R., Gállego, M., Alunda, J. M., Portús, M. (2002). Diagnostic techniques to detect cryptic leishmaniasis in dogs. Clinical and Diagnostic Laboratory Immunology, 9(5), 1137-1141. doi: 10.1128/CDLI.9.5.1137

Instituto Brasileiro de Geografia e Estatística (2017). IBGE cidades. Recuperado de https://cidades.ibge. gov. br/brasil/rs/uruguaiana/panorama

Lachaud, L., Marchergui-Hammami, S., Chabbert, E., Dereure, J., Dedet, J. P., \& Bastien, P. (2002). Comparison of six PCR methods using peripheral blood for detection of canine visceral leishmaniasis. Journal of Clinical Microbiology, 40(1), 210-215. doi: 10.1128/JCM.40.1.210-215.2002 
Mahmud, I. C., Piassini, L. de A. S., Motta, F., Behar, P. R. P., \& Souza, G. D. (2019). Epidemiological aspects of the first human autochthonous visceral leishmaniosis cases in Porto Alegre, Brazil. Brazilian Journal of Infectious Diseases, 23(2), 124-129. doi: 10.1016/j.bjid.2019.04.004

Organización Panamericana de la Salud (2019). Manual de procedimientos para Vigilancia y Control de las Leishmaniasis en Las Américas. Washington, D. C.: Organización Panamericana de la Salud.

Rosa Cruz, C. F., Rosa Cruz, M., \& Galati, E. A. B. (2013). Sandflies (Diptera:Psychodidae) in rural and urban environments in an endemic area of cutaneous leishmaniasis in southern Brazil. Memórias do Instituto Oswaldo Cruz, 108(3), 303-311. doi: 10.1590/S0074-02762013000300008

Salomón, O. D., Basmajdian, Y., Fernández, M. S., \& Santini, M. S. (2011). Lutzomyia longipalpis in uruguay: The first report and the potential of visceral leishmaniasis transmission. Memorias do Instituto Oswaldo Cruz, 106(3), 381-382. doi: 10.1590/ S0074-02762011000300023
Salomón, O. D., Sinagra, A., Nevot, M. C., Barberian, G., Paulin, P., Estevez, J. O., Riarte, A., Estevez, J. (2008). First visceral leishmaniasis focus in Argentina. Memorias do Instituto Oswaldo Cruz, 103(1), 109111. doi: 10.1590/S0074-02762008000100018

Sambrook J, Russel DW (2001). Molecular cloning: a laboratory manual. (3rd ed.). New York: Cold Spring Harbor.

Satragno, D., Faral-Tello, P., Canneva, B., Verger, L., Lozano, A., Vitale, E., Greif, G., Soto, C., Robello, C., Basmadjián, Y. (2017). Autochthonous outbreak and expansion of canine visceral Leishmaniasis, Uruguay. Emerging Infectious Diseases, 23(3), 536538. doi: 10.3201/eid2303.160377

Sistema de Informação de Agravos de Notificação, Secretaria de Vigilância em Saúde, Ministério da Saúde (2019). Casos confirmados de Leishmaniose visceral, Brasil, grandes regiões e unidades federadas 1990 a 2018. Recuperado de https:// portalarquivos2.saude.gov.br/images/pdf/2019/ outubro/14/LV-Casos.pdf 
